\title{
DEPRECIATION METHODS AND RATES AS AN INSTRUMENT OF OPTIMIZATION OF DIRECT TAXES
}

\author{
WIESEAWA MIEMIEC ${ }^{l}$
}

\begin{abstract}
Depreciation of fixed assets and intangible assets is a crucial instrument having the impact on the structure of costs related to income taxes. Depreciation enables the taxpayer to "regain" money spent on the purchase of used assets. Selection of a suitable depreciation method as well as the right to change the depreciation rate not only enables the taxpayer to have an influence on the duration of the depreciation process but also on the amount of depreciation write-downs determining the amount of the tax base and the amount of tax. In this way, the taxpayer can also legally reduce the tax obligation.
\end{abstract}

\section{Keywords}

Tax-deductible expenses; depreciation of fixed assets; depreciation write-down; depreciation method; depreciation rate

\section{JEL Classification: H26, K34, K42}

\section{Introduction}

In colloquial language "optimization" is understood as the "organization of specific actions, processes so that they resulted in the biggest possible effects and involved the least amount of labor" (Słownik języka polskiego PWN). Polish tax regulations do not define tax optimization. Tax law doctrine helps establish this term. Following one of the ideas, tax optimization is understood as tax planning the aim of which is to create the best solutions as regards tax burdens, related to current or investment business activities taken by taxpayers (Wyciślok, 2013: 29). So, it is

1 Doctor, professor, Department of Financial Law, Faculty of Law, Administration and Economy at the University of Wrocław. Contact email: wieslawa.miemiec@uwr.edu.pl. 
a choice of the variant of completion of a given economic outcome resulting in the legal reduction of tax burdens. Tax optimization is a legal form of reduction of tax burdens provided to the taxpayer by the legislator in order to reduce, among other things, tax burdens (Olesińska, 2013: 26). In practice, they are often connected with institutions avoiding taxes (tax evasion is a legal action of the taxpayer aiming at the decrease in tax burdens, often referred to as the grey market. The taxpayer as part of applicable laws takes specific undertakings leading to the decrease of the final tax below the level treated by the legislator as adequate in relation to specific situation resulting in tax and legal consequences (Kalinowski, 2001: 24; Olesińska, 2013: 27) or evading taxation (tax evasion consists of a situation in which the taxpayer is involved in illegal actions the aim of which is to decrease tax burdens. They include actions of the taxpayer aiming directly at the violation of applicable norms and the fiscal law (e.g. suppression of facts before the tax authority resulting in tax obligation, preparation of forged tax returns). All such behaviors constitute the breach of statutory tax rules and are subject to the penalty pursuant to the Penal and Fiscal Code of 10 September 1999. However, these apparently similar institutions have the different meaning in the tax law system.

For the purpose of this survey, I treat tax optimization as a process that encompasses the elements of planning, anticipating and knowledge of the law and makes use of depreciation of a fixed asset to bring on the legal reduction of tax burdens. First of all, the concept of depreciation of a fixed asset, its functions, and a legal structure have to be explained to discuss methods thanks to which depreciation of fixed assets can contribute to reduce such burden.

\section{Concept and Functions of Depreciation of Fixed Assets in the Corporate Income Tax System}

Depreciation is both an economic and legal category. From the economic point of view, depreciation reflects usage of fixed assets in the process of manufacture and gradual reallocation of its value to new products (Swatler, 1983: 16). The process reflects the pecuniary loss of the value of fixed assets used in business activity as a result of its usage or aging and reallocating it to a newly manufactured or purchased asset. The literature distinguishes its three basic functions, i.e.: amortization function, also referred to as a measure of depreciation of fixed assets, cost function and reinstatement function (Sawicka, 1988: 103).

As the depreciation process moves on through the agency of depreciation writedowns, the amortization function decreases the fair value of a given fixed asset, adjusting it to its current value. The cost function says that depreciation is an element 
of costs of the business activity. In other words, depreciation write-downs are classified together with other expenses as the costs of action in a given accounting period. According to the reinstatement function, depreciation enables to replace used and old fixed assets with the new ones. As the depreciation process moves on, funds are obtained gradually that enable to purchase new elements of fixed assets. All these functions are closely inter-related. As part of the cost function, depreciation is a parameter of economic result that enables to make development decisions.

The depreciation process thus perceived is complex. It comprises a few stages and requires specific record and calculation operations. Apart from reallocating the cost of the tangible asset over manufactured goods, it also covers accounting and booking records of the decrease in the value of the assets, measurement of such decrease in cash in form of depreciation write-downs and collection of funds coming from depreciation write-downs in form of depreciation fund that enables reinstatement of used property (Andrzejczak, Mikina, Rzeźnik, Wajgner, 2010: 107). These stages are referred to in a legal regulation included in the accountancy act (Accountancy Act of 29 September 1994) and the tax regulations. The main purpose of depreciation as part of the balance sheet law consists in defining a real value of tangible assets as at the end of the settlement period. Unlike the balance sheet law, tax depreciation refers to taxpayers of income tax and in a separate legal regime regulated by the act, it enables to reduce tax obligation by way of charging amounts of write-downs to tax deductible expenses. Due to the subject matter of the survey further deliberations are limited to legal and tax aspects of depreciation.

Legal and tax depreciation structure of tangible assets are stipulated in the income tax acts, i.e. Personal Income Tax Act ("PITA") and the Corporate Income Tax Act ("CITA"). These regulations specify as per very similar rules the subject of depreciation, calculation basis and the amount of the depreciation write-downs, depreciation methods and the amount of the applied depreciation rates. However, no legal concept of depreciation has been formulated there. Reference books say that "depreciation is one of the methods of recognizing expenses of the taxpayer incurred on the manufacture or purchase of specific assets, tax-deductible expenses in the profit and loss account" (Mariański, Strzelec, Wilk, 2012: 332).

According to the provisions of both income tax acts, depreciation refers to fixed assets owned or co-owned by the taxpayer with the expected useful life of more than a year, purchased or manufactured on its own, complete and fit for use on the day they have been accepted for use, used by the taxpayer for the purposes connected with its business activity or put into use based on rental, tenancy or financial lease agreement (Art. 22a/1 and Art. 22b/1-3 of PITA and Art. 16a/1 and Art. 16b/1-3 of CITA). The aforementioned acts list the elements of property classified as fixed 
assets that are subject to depreciation, irrespective of the expected useful life, e.g. buildings and structures built on a third party's land (Art. 22a/2 of PITA and Art. 16a/2 CITA). Pursuant to Art. 22b/1 and 2 of PITA and Art. 16a/1 and 2 and Art.16b/11 and $2 \mathrm{~b}$ of CITA, also intangible assets are subject to depreciation. For depreciation write-downs to be made, the requirement referred to in Art. $22 \mathrm{~d} / 1$ of PITA and Art. 16d/1 of CITA is of a great importance, pursuant to which assets with the fair value exceeding 3,500 PLN are subject to depreciation. If the value of an asset is equal or lower than 3,500 PLN, the taxpayer can renounce making depreciation write-downs, and expenses incurred to purchase them can be classified as tax-deductible expenses in a month in which they were put into use (Art. 22d/1 of PITA and Art. 16d/1 of CITA; the literature sometimes defines such possibility as one-off depreciation write-down (Mazur, 2009: 354). The legislator has also created a catalog of tangible assets excluded from depreciation, e.g. land and the right of perpetual usufruct of land (Art. 22c of PITA and Art. 16c of CITA).

Thus, components being subject to depreciation have to fulfill conditions specified by the legislator. As far as the fixed assets are concerned, such conditions include among other things the requirement of the ownership or co-ownership right to be held by the taxpayer, the assets have to be manufactured or purchased internally, the assets have to be complete and fit for use on the date they have been accepted by the user, the expected useful life is to be longer than one year, and used funds are to be allocated for purposes connected with the taxpayer's business activity.

\section{Method, Write-Down and Depreciation Rate}

The depreciation method specifies the manner and speed of collecting cash (depreciation fund) that enables reinstatement of used assets. There are a few depreciation methods: a proportional method, also referred to as a straight-line method, a declining balance method, and a progressive method. In case of the straight-line method, the annual amount of depreciation is calculated on the same basis (i.e. on the gross value of the asset) and with the use of the same depreciation rate (fixed rate). The declining balance method consists in adopting the same rate to calculate due to depreciation write-down but related to the current value of the fixed asset, i.e. to the net value decreased by already made depreciation write-downs. Finally, the progressive method consists in calculating write-downs based on the gross value of fixed assets with the use of variable depreciation rate increasing year by year.

As a result, the taxpayer obtains the information on the amount of depreciation of its fixed assets. The amount expressing such decrease in the value of fixed assets in a specific period of time constitutes the depreciation write-down. Such write- 
down is an instrument directly influencing the amount of tax-deductible expenses, and therefore, the amount of income and tax base as regards income taxes. Pursuant to Art. 22/8 of PITA and Art. 15/6 of CITA, depreciation write-downs include write-downs related to wear and tear of fixed assets and intangible assets that will be recognized as tax-deductible expenses provided that they will be made in accordance with the rules provided for in Arts. 22a-o of PITA, taking account of Art. 23 of PITA and Arts. 16a-m of CITA and Art. 16 of CITA.

The taxpayer choosing a suitable depreciation method should take into account effectiveness of a fixed asset, and the period as well as intensiveness of its operation. It should also not only adjust the speed of physical wear and tear of the fixed asset up to the speed of depreciation but also ensure that depreciation write-downs constituting tax-deductible expenses related to income taxes reached the highest possible level and were also appropriately spread over a period of time taking account of a financial standing of the taxpayer and purposes of its business activity.

The depreciation rate is a percentage value of a fixed asset (on a year-to-year basis) the taxpayer can recognize in a given year as tax-deductible expenses. Due to universality, both acts mentioned herein apply interest rates the name of which as well the amount and the symbol in the Classification of Fixed Assets (Decree of the Council of Ministers dated 3 October 2016 on the Classification of Fixed Assets, Journal of Laws item1864 as amended (CFA) are included in the list constituting an appendix no. 1 to such acts. Thus, the taxpayer can easily establish and assign a given fixed asset to a suitable category, and what follows - to a suitable annual depreciation rate. There are exceptions to the aforementioned general rule that enables the taxpayer, in accordance with statutory requirements, to increase or decrease the rate stipulated in the list. According to Art. 22i of PITA and Art. 16i of CITA, in situations established therein the taxpayer can increase or decrease the depreciation rate in comparison to the amount of the rates provided for in the List of Fixed Assets. It is optional for the taxpayer to use decreased or increased rate but at the same time it involves fulfillment of statutory requirements. As not every fixed asset meets object- and time-related criteria qualifying it within a given group defined in the List of Fixed Assets, the act allows for an individual rate with reference to fixed assets defined in Art. 16j of PITA and in Art. 22j of CITA. In this case, the depreciation period related to such fixed assets is limited pursuant to the act to the period of time specified therein.

The right to change the depreciation rate and to use the individual rate enables the taxpayer to have the impact on increasing the amount of the depreciation writedowns, and thus shortening the depreciation period. It is also a starting point for the preparation of a strategy enabling optimization of income tax burdens. 


\section{Methods of Reducing Income Tax Burdens with the Use of Depreciation}

Appropriate planning of tax burdens and the knowledge of regulations related to depreciation of the taxpayer's assets can result in a legal decrease of tax burdens. Depreciation as a financial and legal institution generating costs can contribute to the application of tax regulations so that the costs were not only optimal but also occurred in a specific time horizon. Taking into account legal rules determining depreciation, it should be assumed that the following can be deemed to be optimization instruments in the analyzed scope:

- the possibility of changing rates in the straight-line method;

- the depreciation with the use of declining balance method;

- the one-off depreciation;

- the depreciation as per individual rates.

These are not all possible methods resulting in the decrease in income tax burdens (tax optimization). There is also the so-called lease back or dwelling premises improved or used before they have been purchased but they are quite rare in practice and therefore they will be skipped in further considerations.

\subsection{Taxpayer's Right to Increase or Decrease the Depreciation Rate in the Straight-Line Method}

The straight-line method is the basic depreciation method provided for in income tax acts. Pursuant to Art. 22f of PITA and Art. 16f of CITA, taxpayers, with the exception of those who do not conduct business activity due to declared bankruptcy covering liquidation of the assets, make depreciation write-downs of the fair value of fixed assets and intangible assets. In Art. 22g of PITA and in Art. 16g of CITA, a normative concept of the fair value was established. In case of a purchase, this value corresponds to the purchase price. In case of internal manufacture, it corresponds to the cost of manufacture. In case of acquisition by way of inheritance, donation or other acquisition free of charge - it is a market value as of the date of purchase unless a lower value has been determined in the contract related to such acquisition free of charge. The act also allows for a possibility of establishing a different fair value of fixed assets by the taxpayer. Pursuant to Art. 22g/1/6 and 7 of PITA and Art. $16 \mathrm{~g} / 1 / 6$ and 7 of CITA, taxpayers who purchased fixed assets by way of performance for them of non-pecuniary obligation in place of the performance of the obligation contract (datio in solutum), can adopt the market value of the assets as their fair value unless the contract for supplementary performance specifies a lower value. Also, foreign taxpayers who conduct business in the territory of Poland 
through the agency of a foreign plant can adopt other value of fixed assets as the fair value. In such case, it is the value of individual elements adopted for tax purposes that results from the books of such taxpayer, however, no higher than the market value of such assets. The provisions of the act provide for a condition that all writedowns in a given tax year cannot exceed the equivalence of 50 thousand EUR.

Pursuant to Art. 22h/44 of PITA and Art. 16h/4 of CITA, taxpayers who apply the straight-line method make depreciation write-downs in equal installments on a monthly or quarterly basis, or on a one-off basis at the end of the tax year. Following this method, depreciation write-downs are made in equal installments depending on the decision made by the taxpayer, on a monthly or quarterly basis, or on a oneoff basis at the end of the tax year. The first month following the month in which a given fixed asset has been put in the records shall be deemed to be the beginning of depreciation, until the end of the month in which the sum of depreciation writedowns is equal to their fair value or in which they were declared bankrupt, sold, or their shortage was stated. The date of putting the fixed asset into use is important as well as the fact whether the asset meets other conditions provided for in the law, e.g. whether it was complete and fit for use on that day.

The straight-line method enables even wear and tear of a given fixed asset during the period of its useful life, based on fixed depreciation write-downs during the whole period of depreciation. In situations indicated in Art. 22i of PITA and Art. 16i of CITA, the taxpayer can bring on increasing or decreasing the amount of the depreciation write-downs and in consequence speed up or slow down the period of depreciation (Małkowska, 2002: 166). Such result can be obtained by way of using the taxpayer's right to change the amount of depreciation rate in comparison to the amount given in the list of depreciation rates. As a result, due to the depreciation rate, the straight-line method can have a form of accelerated or decelerated depreciation (Ożóg, 2000: 93).

Optionality of choice made by the taxpayer should be justified not only by tax optimization but also by financial standing of the taxpayer. Pursuant to Art. 22i/2 of PITA and Art. 16i/2 of CITA, taxpayers can increase basic rates of specific assets that are used in special conditions and establish at the same time the limit for increasing the coefficient of basic rates provided in the list constituting the appendix to the aforementioned acts, i.e.:

- for buildings and structures used in deteriorated conditions - with the use of coefficients not higher than 1.2, or in bad conditions with the use of coefficients not higher than 1.4;

- for machinery, devices and means of transport, with the exception of floating marine fleet, used more intensively in relation to average conditions 
or requiring special technical efficiency - with the use of coefficients not higher than 1.4;

- for machinery and devices classified within groups 4-6 and 8 of fixed assets, being subject to rapid technical development - with the use of coefficients not higher than 2.0.

Explanations attached to the List of rates include open catalogues with examples of situations that enable to apply the increased rate, i.e. deteriorated conditions (a catalogue of such situations is open, section 1 of the explanations says that among other things it is about using fixed assets being under the constant influence of water, steam, significant vibrations or sudden changes in temperature), bad conditions (according to section 2 of the explanations, it concerns fixed assets being under the influence of destructive chemical agents), special technical efficiency (according to section 3 of the explanations, special technical efficiency is understood as facilities which are used on a three-shift work basis, or in field conditions, in the first or under the ground), rapid technical development (according to section 4 of the explanations, rapid technical development is understood as machinery, devices, and apparatus in which microprocessor or computer systems are used).

Possible use of the increased rate is limited by an admissible limit that cannot be exceeded by the taxpayer. One selected coefficient can be applied as regards individual fixed assets. Increased rates mean that the basic rate provided for in the List of rates is multiplied by a given coefficient. Further depreciation writedowns have to be made in accordance with the rules applicable to the straight-line depreciation method. The increased rate in situations provided for in Art. 22i/2 sections 1-2 of PITA and Art. 16i/2/1-2 of CITA can be used starting the month following the month in which circumstances justifying such increase took place. As regards machinery and devices being subject to rapid technical development, taxpayers can increase or stop using them starting the month following the month in which such assets were put in the records or starting the first month of each following tax year. The literature says that after circumstances justifying the taxpayer's right to increase the rate have ceased to exist, the taxpayer shall be obliged to decrease it (Nykiel, Mariański, 2014: 612-613).

Pursuant to Art. 22i/5 of PITA and Art. 16i/5 of CITA, taxpayers can also decrease depreciation rates of individual fixed assets depreciated with the use of the straightline method provided in the List of Fixed Assets. Unlike given situations, the act does not state that the basic rate can be decreased provided that some specific conditions have been fulfilled. There is also no limit as regards the decrease in the rate of a concrete fixed asset and the obligation to meet the acceptable dates for the implementation of such decrease. Following the aforementioned regulations, the rate is changed starting the month in which assets were put in the records or starting 
the first month of each following tax year. The taxpayer can return to previous rates at any time on condition that they do not exceed maximum limits provided for the basic depreciation rates specified in the List. It results from the same wording of the regulations which enable to decrease rates without any additional requirements in this scope.

Thus, the straight-line method can be deemed to be quite flexible and providing for a possibility of changing the depreciation rate during the depreciation period it enables to adjust the amount of depreciation write-downs to current needs and tax burdens of the taxpayer (provided that the rate does not exceed the maximum amount specified in the list of depreciation rates). The use of the increased depreciation rate involves increase in the amount of depreciation write-downs. It results in the increased tax-deductible expenses related to income tax, and in consequence, in the decrease in due and payable obligation on this account. It also results in a shortened depreciation period, faster obtaining of depreciation fund that enables not only reinstatement of used fixed assets but also faster reimbursement of expenses incurred on the fixed assets. The decision on making depreciation stages faster by way of increasing the rate has to be made by the taxpayer after taking account of its financial standing. If the fixed assets are not being as much worn or when the taxpayer suffers financial loss for a longer period of time, the possibility of decreasing the depreciation rate is a useful instrument. When suffering loss, the taxpayer does not generate any taxable income but there might be a risk that it will not make it to deduct the loss from income in the following 5 years pursuant to Art. 9/5 of PITA and Art. 7/5 of CITA (the amount in any of these years cannot exceed $50 \%$ of the amount of loss). Prolongation of the depreciation process enables the taxpayer to decrease income in the next years (Wójtowicz-Janicka, 2012: 207, 210). It has also a positive outcome. The taxpayer can settle the loss in its full amount without losing cost generated by depreciation write-downs. It should be mentioned that the taxpayer can freely choose fixed assets for which the rate will be decreased. The act does not also provide for limits as regards the decrease of the depreciation rate (with the exception of the rate established individually which does not change during the whole depreciation period). Thus, the question if the depreciation rate can approach zero is reasonable. The act does not specify any limits, thus, it should be assumed that it is admissible. Such stance has been adopted in the reference books (Wójtowicz-Janicka, 2012: 211) and in some interpretations of tax authorities (individual interpretation: no. IBPBI/1/423-37/11/ZK, individual interpretation: no IPPB5/423-161/10-2/AM). 


\subsection{Depreciation Made with the Use of the Declining Balance Method}

The principles governing the declining balance method are different. According to Art. $22 \mathrm{k} / 1-13$ of PITA and Art. 16k/1-13 of CITA, the declining balance method can only be used in relation to some assets, i.e. machinery and devices classified within the groups 3-6 and 8 of the Classification of Fixed Assets and to means of transport, excluding buildings and vehicles. This method is characterized by a variable, decreasing base for depreciation write-downs. During the first year, the amount of depreciation write-down is established on the basis of the fair value of a fixed asset according to the rules applicable with reference to the straight-line method. During successive years the amount of depreciation write-down is calculated based on the fair value of the fixed asset decreased by the sum of already made write-downs established at the beginning of successive years of use. So, it is the net value of the fixed asset. Decreasing base causes that also depreciation write-downs decrease, thus, this method is called the declining balance method (wwwsjp.pwn.pl).

Such base constituting the net value of the fixed asset serves as a basis for establishing depreciation write-down calculated with the use of the rate increased by a coefficient not higher than 2.0. The depreciation process would take a lot of time based on such rules, thus, starting the tax year in which the annual amount of depreciation specified based on the aforementioned rules would be lower than the annual amount of depreciation calculated with the use of the straight-line method and basic rates included in the List of depreciation rates, the taxpayer is obliged to make further write-downs with the use of the straight-line method according to Art. 22i/1 of PITA and Art. 16i/1 of CITA. After moving to the straight line method, pursuant to Art. 22i/2-7 of PITA and Art. 16i/2-7 of CITA, the taxpayer can make depreciation write-downs choosing the fixed or variable rate.

The advantage of using the declining balance method consists in a possibility of speeding the depreciation process in the first two years of using the fixed asset, i.e. in the period of its highest efficiency, as well as a possibility of faster use of financial surplus towards which profit and the amount of the depreciation writedowns are applied. Owing to the increased tax-deductible expenses, the payment of income tax is shifted in time. This method also has some defects. In the initial period of use of fixed assets with the use of this method, a higher cost of the activity will be experienced. Thus, profit obtained by the taxpayer will be lower. Depending on the financial standing of the taxpayer, all these consequences should be taken into account. 


\subsection{One-off Depreciation}

The provisions of Art. 22k/7-13 of PITA and Art.16k/7-13 of CITA provide for a possibility of making one-off depreciation write-offs of the fair value of fixed assets classified within groups 3-8 of the Classification of Fixed Assets, i.e. machinery, devices and means of transport, excluding passenger cars. So, fixed assets classified within groups 3-8 can be depreciated on a one-off basis.

Small business taxpayers and taxpayers commencing their business activity (only during the first tax year) have the right to apply (every year) one-off depreciation method) (small business taxpayer in 2017 in accordance with Art. 5a/20 of PITA, Art. $4 \mathrm{a} / 10$ of CITA refers to the taxpayer whose sales income and due VAT in 2014 did not exceed the amount expressed in Polish PLN corresponding to the equivalence of 1.2 million EUR per year). Such possibility can be used by income taxpayers commencing their activity in the tax year during which such assets were put in the records of fixed assets and intangible assets up to the amount not exceeding the equivalence of 50 thousand euro of the total amount of such depreciation writedowns in the tax year (in 2017 the amount was 215 thousand PLN).

Depreciation write-downs made with the use of such preferential method does not apply according to Art. $22 \mathrm{k} / 11$ of PITA to taxpayers that in the tax year and within two years starting the end of the year preceding the year of commencement of activity were conducting business activity independently or as partners of a company not being a legal person or such activity was conducted by a spouse of such person if there was marital community property between spouses. In Art. $16 \mathrm{k} / 11$ of CITA, the act excludes the possibility of making one-off depreciation by the taxpayer that was established as a result of transformation, merger or division of taxpayers or as a result of transformation of the company not being a legal person, or by natural persons who provided their enterprise or assets of such enterprise towards the capital of a new entity with the value exceeding jointly the equivalence in Polish PLN of at least 10.000 EUR.

The possibility of applying this method should be treated as a specific tax relief. Art. $22 \mathrm{k} / 10$ of PITA and Art.16k/10 of CITA treat it as de minimis aid (de minimis aid is a special category of support granted by the state as it is assumed that due to its minor value it does not disturb competition in the EU. Therefore, it is not, in fact, public support within the meaning of Art. 107/1 of TFUE, and in consequence, it is not subject to the obligation of notification of the European Committee. The rules of providing de minimis aid have been defined in the Decree of the Committee (EC) no. 1998/2006 in connection with Art. 87 and 88 of the Treaty to the de minimis aid, Journal of Laws of the EU of 2006, L 379/5). Implementation of such rule causes that the circle of taxpayers applying one-off depreciation method is limited. It can 
only be used by the taxpayers that are entitled to such aid and have not used in full their limit.

The (gross) fair value of fixed assets in the tax year during which they were put in the records is the basis for making depreciation write-downs following this method. This value is established according to the rules included in Art. 22g/1/6 of PITA and Art. $16 \mathrm{~g} / 1 / 6$ of CITA. Selection of the type of method in the following years is also the taxpayer's right. It will have to decide on further depreciation method taking into account not only its own financial standing but also advantages and defects of the straight-line method or declining balance method. Such solution created an investment stimulant for small taxpayers as it contributed to reducing the amount of income tax due in a given year and enabled to use flexible rules for the settlement of depreciation. Due to subject limitations (it was to be used by a small group of taxpayers) and object limitations (it concerned selected assets), as well as the necessity to prepare additional documentation (one-off depreciation write-off constituted de minimis aid) it was not used to a great extent in practice.

On 7 July 2017 another amendment to PITA and CITA was passed, enabling oneoff depreciation to be made in relation to purchased owned or co-owned new fixed assets classified within groups 3-6 and 8 of the Classification of Fixed Assets in the tax year in which these assets were put in the records up to the amount not exceeding the amount of 100,000 PLN in the tax year, covering the sum of depreciation write-downs and payments made by the taxpayer towards the purchase of such fixed assets (Art. 22k/14-21 of PITA and Art.16k/14-21 of CITA). The possibility of applying this preferential method depends on the fulfilment by the taxpayer of conditions provided for in quoted regulations, namely, the fair value of one new fixed asset purchased in the tax year should be at least 10,000 PLN or the aggregate fair value of at least two new fixed assets purchased in the tax year should amount to at least 10,000 PLN and the fair value of each of them should exceed 3,500 PLN (Art. 22k/14-15 of PITA and Art. 16k/14-15 of CITA).

If the activity is conducted by a company not being a legal person, the limit of depreciation write-downs in the amount of 100 thousand PLN refers to all partners of such company (Art.22k/19 of PITA and Art. 16k/19 of CITA). This accelerated depreciation method can be used by taxpayers irrespective of the form of activity in relation to expenses for the purchase of brand new fixed assets, i.e. machinery and devices affected since the beginning of 2017. Expenses on used fixed assets, means of transport, including passenger cars, and expenses on real property have been excluded. It is crucial that as part of the annual limit it is possible to recognize payments (advance payments) for the purchase of a fixed asset meeting the requirements also when such asset will be delivered within the following reporting periods (next month, quarter or year). According to this rule, the taxpayer that 
has exhausted the limit within one tax year and could not recognize the advance payment for the purchase of fixed assets towards tax-deductible expenses, will have the right in the following year to decrease the amount of one-off depreciation writeoff by previously paid advance payment after the fixed asset has been purchased. However, if the delivery is not affected the taxpayer shall be obliged to correct taxdeductible expenses (Art. 22k/21 of PITA and Art. 16k/21 of CITA). This relief is to encourage mainly micro, small and medium-size companies to purchase new machinery and devices that can significantly increase their competitiveness. However, it is hard to assess whether the expected results will be reached. The new regulation has not been implemented yet.

\subsection{Depreciation as per Individual Rates}

The possibility of making depreciation write-downs with the use of individual rates is applied in relation to the straight-line method. It consists in establishing an individual depreciation rate as regards used or improved purchased fixed assets, put for the first time in the records of the fixed assets of the taxpayer (Art. 22j/1 of PITA and Art. 16j/1 of CITA). The possibility of using this method depends on the cumulative fulfillment of two conditions by the fixed assets. First, they have to be considered as used or improved within the meaning of the act (par. 2 and 3 of the aforementioned regulations) and have to be put for the first time in the taxpayer's records. These rates are only limited by the period of depreciation specified in the aforementioned acts. Depreciation period is established for individual types of fixed assets and cannot be shorter than:

1) for fixed assets classified within group 3-6 and 8 of the Classification:

a) 24 months - when their fair value does not exceed 25.000 PLN,

b) 36 months - if their fair value is higher than 25.000 PLN and does not exceed 50.000 PLN,

c) 60 months - in other cases.

2) for means of transport, including passenger cars - 30 months,

3 ) for buildings (premises) and structures referred to in Art. $22 \mathrm{j}$ par.1 section 3 of PITA and Art. 16j/1/3 of CITA - 10 years,

4) for buildings (premises) and dwelling structures for which the basic rate in the List of rates amounts to $2.5 \%$ - 40 years, decreased by a complete number of years that have passed since the date of putting them into use for the first time until the date of putting them in the records kept by the taxpayer, whereas the depreciation period cannot be shorter than 10 years. The aforementioned regulations define separately the concept of used fixed asset (used fixed assets referred to in par. 1 sections 1 and 2 refer to assets if 
the taxpayer proves that they had been used for at least 60 months before they were purchased) and improved fixed assets (improved fixed assets referred to in par. 1 sections 1 and 2 refer to assets if before putting them in the records expenses incurred by the taxpayer for such improvement constituted at least $20 \%$ of the fair value) depending on their type. The act provides also for a possibility of establishing the individual rate for investments in the third party fixed assets accepted for use (Art. 22j/4 of PITA and Art. 16j/4 of CITA).

In practice, individual depreciation rates are used with reference to premises and buildings depreciated with the use of the straight-line method as per low rates, as well as in relation to expensive passenger cars. In the second case, according to Art. 23/1/4 of PITA, depreciation write-downs do not constitute tax-deductible expenses in the part established on the value of the car exceeding the equivalence of 20.000 EUR. Thus, establishing the costs of depreciation write-downs in the records, they should be presented in accordance with Art. 21/1/4 of PITA, in the proportion resulting from the value of the car and the amount of 20.000 EUR. The use of low depreciation rate is cost-effective especially when such car is to be sold. Then the fair value is higher, not covered by depreciation write-downs, constituting costs of paid disposal of the car. The economic result obtained by the taxpayer by way of using individual rates is similar to the result obtained in case of using the declining balance method. It enables to speed up depreciation and accumulation of costs related to depreciation write-downs.

\section{Conclusions}

The aforementioned arrangements show that depreciation methods of individual fixed assets of the taxpayer and a type of applied depreciation rates as well as the amount of the depreciation write-downs have a crucial impact on the level of taxdeductible expenses in a given settlement period. They determine the amount of income reached by the taxpayer as well as the amount of income tax due.

The taxpayer chooses the depreciation method taking account conditions related to the object of depreciation. Thus, the taxpayer has to decide which method provided for in applicable provisions would be the most advantageous solution as regards the taxpayer's financial standing. If the taxpayer assumes that the fixed assets will be worn quickly or its value will decrease rapidly, it has to consider the declining balance method characterized by the increased value of depreciation write-downs at first stages of depreciation. If the taxpayer is in a good financial situation and cares about the fixed amount of depreciation write-downs, it should apply the straight-line method. Systematic depreciation made with the use of the straight-line 
method and a fixed rate enables to lower advance payments for income tax and is more profitable when the taxpayer regularly pays significant amounts of advances on account of the income tax. Selection of the suitable depreciation method and rate is a crucial element of tax planning as regards future tax burdens. Using available legal instruments, the taxpayer can make tax depreciation a significant element of tax optimization.

\section{References}

Andrzejczak, D., Mikina, A., Rzeźnik, B., Wajgner, M.D.: Podstawy działalności handlowej (Basis of commercial activity), Warszawa: WSiP, 2010.

Kalinowski, M.: Granice legalności unikania opodatkowania w polskim systemie podatkowym (Limits of the legality of tax avoidance in the Polish tax system), Toruń: TNOiK, 2001.

Małkowska, D.: Środki trwałe, wartości niematerialne i prawne. Ujęcie podatkowe i rachunkowe (Fixed assets, intangible assets. Tax and accounting aspects), Gdańsk: Ośrodek Doradztwa i Doskonalenia Kadr, 2002.

Mariański, A., Strzelec, D., Wilk M.: Podatek dochodowy od osób prawnych. Komentarz (Corporate tax. Comentary), Warszawa: Wolters Kluwer, 2012.

Mazur, E.: Ustawa o podatku dochodowym od osób prawnych w wyjaśnieniach organów podatkowych. Komentarz. Linie interpretacyjne (Act on corporate income tax in explanations of tax authorities. Comment. Interpretation lines), Warszawa: Wolters Kluwer, 2009.

Nykiel, W., Mariański, A. (eds.): Komentarz do ustawy o podatku dochodowym od osób fizycznych (Commentary to the Act on personal income tax), Gdańsk: ODDK, 2014.

Olesińska, A.: Klauzula ogólna przeciwko unikaniu opodatkowania (General clause against tax avoidance), Toruń: TNOiK, 2013.

Ożóg, I.: Amortyzacja w podatku dochodowym od osób fizycznych i prawnych (Depreciation in personal and corporate tax), Warszawa: Konieczny i Kruszewski, 2000.

Sawicka, K.: Rola instrumentów prawnofinansowych w gospodarce produkcyjnym majątkiem trwałym przedsiębiorstw państwowych (The role of legal and financial instruments in the production economy of fixed assets of state-owned enterprises), Wrocław: Wydawnictwo Uniwersytetu Wrocławskiego, 1988.

Swatler, L.: Amortyzacja i finansowanie remontów a system ekonomiczno-finansowy (Depreciation and financing of repairs and the economic and financial system), Finanse (Finances) no. 5 (1983).

Wójtowicz-Janicka, K.: Amortyzacja ze stawką 0\% u podatnika rozliczającego stratę podatkową (Amortization with a $0 \%$ rate for a taxpayer who settles a tax loss), in: Mazur, Ł.: Optymalizacja podatkowa (Tax optimalization), Warszawa: Wolters Kluwer, 2012.

Wyciślok, J.: Optymalizacja podatkowa. Legalne zmniejszanie obciążeń podatkowych (Tax optimization. Legal reduction of tax burdens), Warszawa: C.H. Beck, 2013. 


\section{Wiesława Miemiec}

Słownik języka polskiego PWN (Dictionary of Polish). wwwsjp.pwn.pl.

EU: Decree of the Committee (EC) no. 1998/2006, on the application of Articles 87 and 88 of the Treaty to State aid to small and medium-sized enterprises active in the production of agricultural products and amending Regulation (EC) no. 70/2001.

PL: Accountancy Act of 29 September 1994, as amended.

PL: Penal and Fiscal Code of 10 September 1999, as amended.

PL: Corporate Income Tax Act of 15 February 1992, as amended.

PL: Personal Income Tax Act of 26 July 1991, as amended.

PL: Decree of the Council of Ministers of 3 October 2016 on the Classification of Fixed Assets, as amended.

PL: Individual interpretation: no. IPPB5/423-161/10-2/AM.

PL: Individual interpretation: no. IBPBI/1/423-37/11/ZK. 